This document was prepared in conjunction with work accomplished under Contract No. DE-AC09-96SR18500 with the U. S. Department of Energy.

\title{
DISCLAIMER
}

This report was prepared as an account of work sponsored by an agency of the United States Government. Neither the United States Government nor any agency thereof, nor any of their employees, nor any of their contractors, subcontractors or their employees, makes any warranty, express or implied, or assumes any legal liability or responsibility for the accuracy, completeness, or any third party's use or the results of such use of any information, apparatus, product, or process disclosed, or represents that its use would not infringe privately owned rights. Reference herein to any specific commercial product, process, or service by trade name, trademark, manufacturer, or otherwise, does not necessarily constitute or imply its endorsement, recommendation, or favoring by the United States Government or any agency thereof or its contractors or subcontractors. The views and opinions of authors expressed herein do not necessarily state or reflect those of the United States Government or any agency thereof. 
Key Words:

Cesium

Tetraphenylborate

Retention: Permanent

\section{ANALYSIS OF TANK 48H SAMPLE HTF-E-05-021}

F. F. Fondeur

D. P. Lambert

S. D. Fink

October 3, 2005

Westinghouse Savannah River Company

Savannah River Site

Aiken, SC 29808

Prepared for the U. S. Department of Energy Under

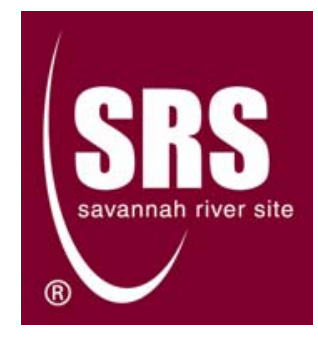

Contract Number DE-AC09-96SR18500 


\section{DISCLAIMER}

This report was prepared by Westinghouse Savannah River Company (WSRC) for the United States Department of Energy under Contract No. DE-AC09-96SR18500 and is an account of work performed under that contract. Neither the United States Department of Energy, nor WSRC, nor any of their employees makes any warranty, expressed or implied, or assumes any legal liability or responsibility for the accuracy, completeness, or usefulness, of any information, apparatus, or product or process disclosed herein or represents that its use will not infringe privately owned rights. Reference herein to any specific commercial product, process, or service by trademark, name, manufacturer or otherwise does not necessarily constitute or imply endorsement, recommendation, or favoring of same by WSRC or by the United States Government or any agency thereof. The views and opinions of the authors expressed herein do not necessarily state or reflect those of the United States Government or any agency thereof.

\section{Printed in the United States of America}

Prepared For

U.S. Department of Energy 


\section{AUTHORS}

\section{REVIEWS AND APPROVALS}
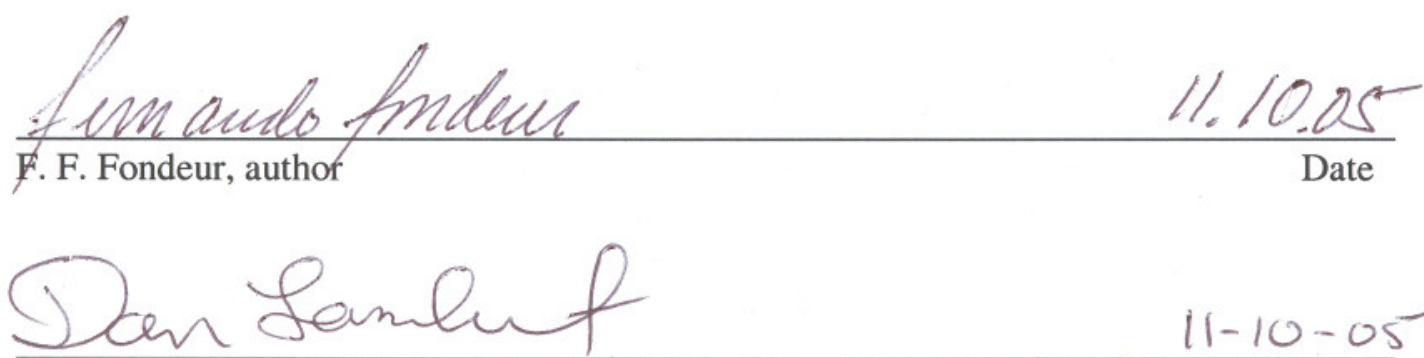

D. P. Lambert, coauthor

Date

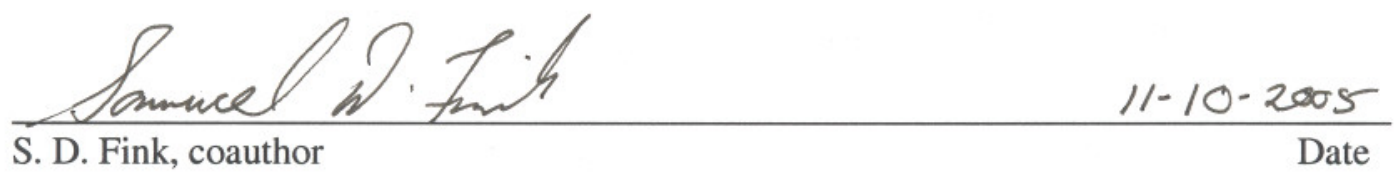

DESIGN CHECK (per Manual E7, Procedure 2.40)

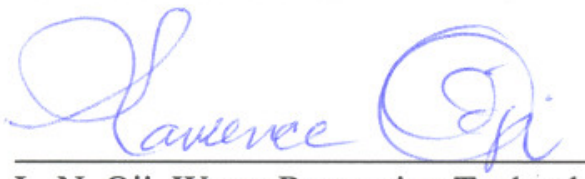

L. N. Oji, Waste Processing Technology

$$
11-10-05
$$

Date

\section{APPROVALS}

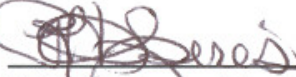

R. H. Spires, Liquid Waste Disposition Project Owner, Tank 48H

\section{$11-18-05$}

Date

M.B. Clendeven for D.T.Conrad

$11 / 18 / 05$

D. T. Conrad, Manager, Low Curie Salt Engineering

Date

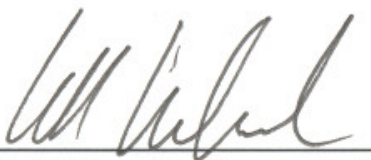

W. R. Wilmarth, Manager, Advance Characterization and Separation Group Waste Processing Technology

Date
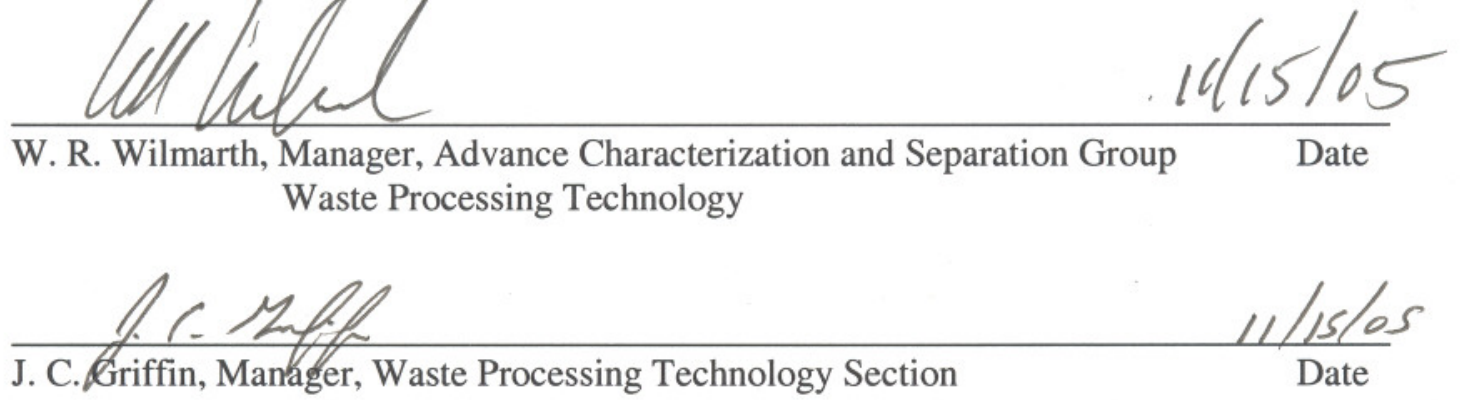


\section{TABLE OF CONTENTS}

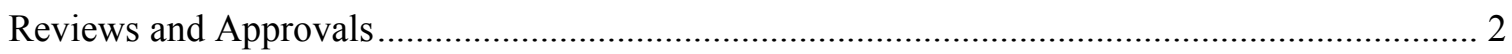

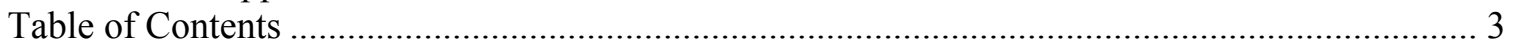

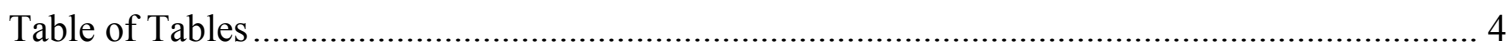

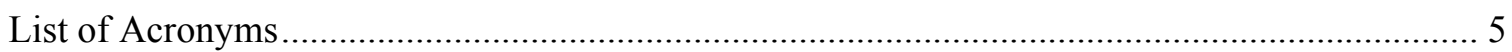

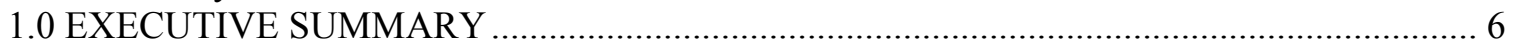

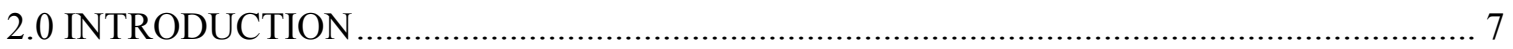

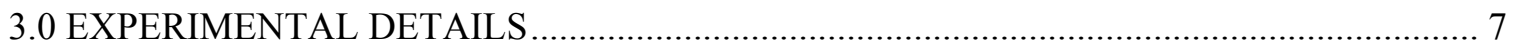

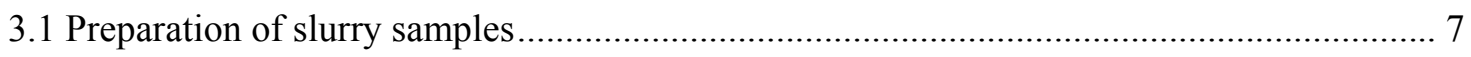

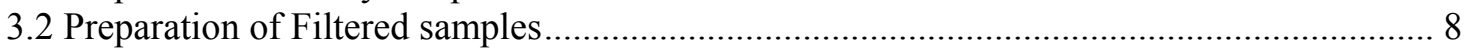

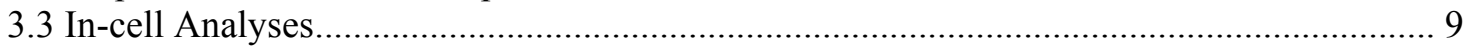

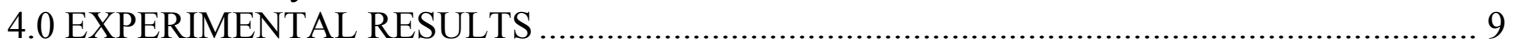

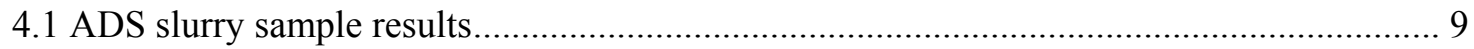

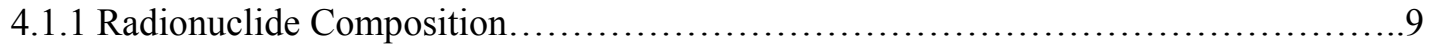

4.1.2 Inductively Coupled Spectroscopy-Emission Spectroscopy ……............................... 10

4.1.3 Inductively Coupled Spectroscopy - Mass Spectroscopy …...................................... 10

4.1.4 Inductively Coupled Spectroscopy - Mass Spectroscopy …....................................... 12

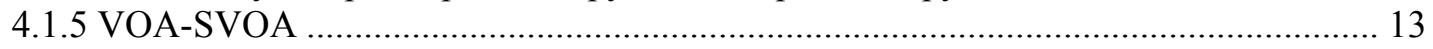

4.1.6 High Performance Liquid Chromatograph.................................... 14

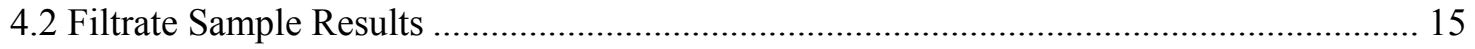

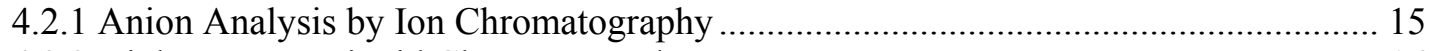

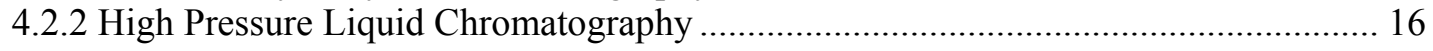

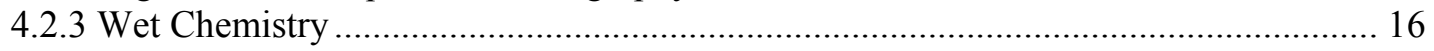

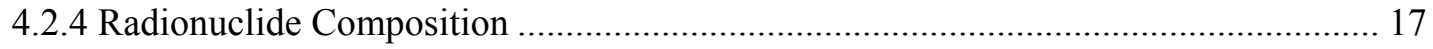

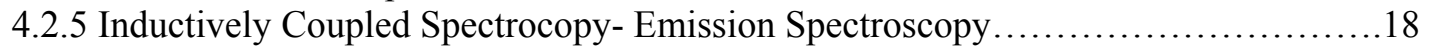

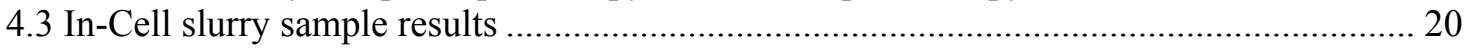

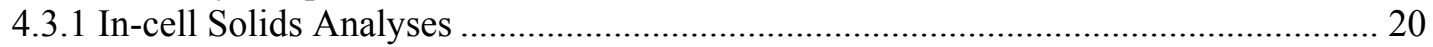

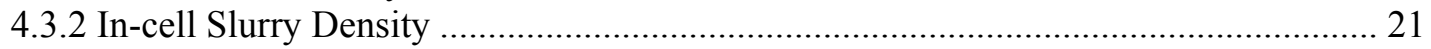

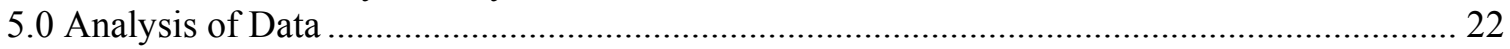

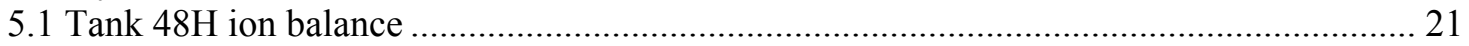

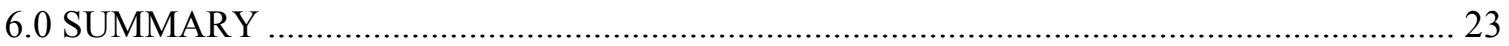

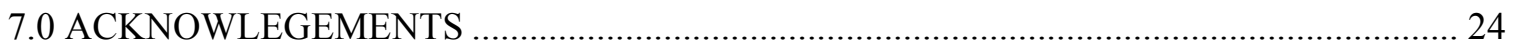

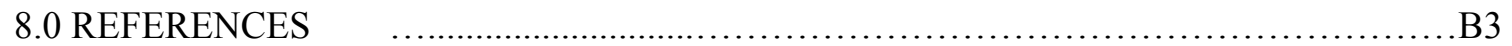




\section{TABLE OF TABLES}

Table 1 - Summary of Significant Tank 48H Sample Results ................................................. 6

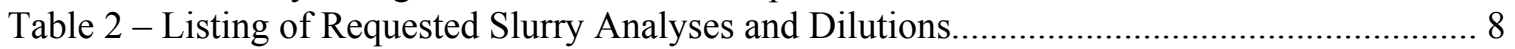

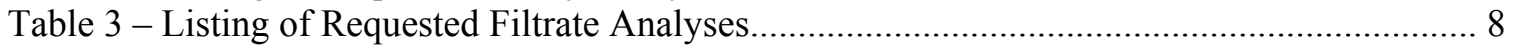

Table 4 - Tank 48H Slurry Radiation Chemistry Analytical Results....................... 10

Table 5 - The ICP-ES results for the digested slurry from the HTF-E-05-21 sample............ 11

Table 6 - The actinide results for the digested slurry from the HTF-E-05-21 sample.............12

Table 7 - List the noble metal composition of the slurry HTF-E-05-021 as determined by

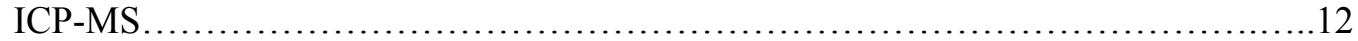

Table 8 - Results from the VOA and SVOA analysis of the slurry HTF-E-05-021 ................... 14

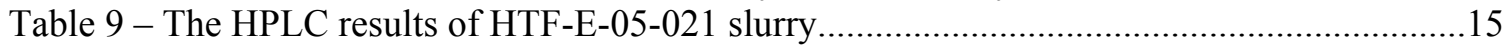

Table 10 - The anion composition of HTF-E-05-021 filtrate sample .........................16

Table 11 - The phenylborate composition of the filtrate as determined by HPLC................16

Table 12 - The base composition of HTF-E-05-021 filtrate sample ......................... 17

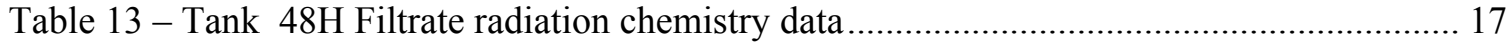

Table 14 - The ICP-MS results of HTF-E-05-021 filtrate sample. The two set values are from

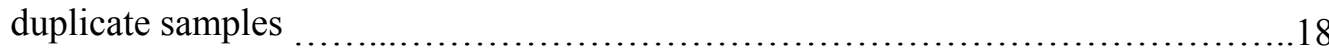

Table 15 - The cation composition of HTF-E-05-021 filtrate sample as determined by ICP-ES. The two set values are from duplicate samples ..................................19

Table 16 - Comparison between HFT-E-05-021 filtrate and previous sample's

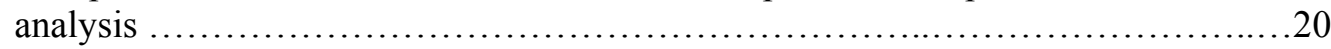

Table 17 - The gravimetric properties of HTF-E-05-021 filtrate sample.....................21

Table18-Composition of the total solid mass for 1 gram of dried solids ......................21

Table19 - Tank 48H Filtrate Anion/Cation Balance...........................................22 


\section{LIST OF ACRONYMS}

\begin{tabular}{|c|c|}
\hline $1 \mathrm{~PB}$ & phenylboronic acid \\
\hline $2 \mathrm{~PB}$ & diphenylborinic acid \\
\hline $3 \mathrm{~PB}$ & triphenylborane \\
\hline $4 \mathrm{~PB}$ & tetraphenylborate anion $-\left[\mathrm{B}\left(\mathrm{C}_{6} \mathrm{H}_{5}\right)_{4}\right]^{-}$ \\
\hline AA & Atomic Absorption \\
\hline ADS & Analytical Development Section \\
\hline CsTPB & Cesium tetraphenylborate $\left(\mathrm{Cs}\left[\mathrm{B}\left(\mathrm{C}_{6} \mathrm{H}_{5}\right)_{4}\right]\right)$ \\
\hline FW & formula weight \\
\hline HPLC & High Performance Liquid Chromatography \\
\hline IC & Ion Chromatography \\
\hline ICP-ES & Inductively Coupled Plasma - Emission Spectrometry \\
\hline ICP-MS & Inductively Coupled Plasma - Mass Spectroscopy \\
\hline ITP & In-Tank Precipitation \\
\hline КТРB & Potassium tetraphenylborate $-\mathrm{K}\left[\mathrm{B}\left(\mathrm{C}_{6} \mathrm{H}_{5}\right)\right]_{4}$ \\
\hline LOD & Limit of Detection \\
\hline MST & monosodium titanate \\
\hline MW & molecular weight \\
\hline NA & not applicable \\
\hline NM & not measured \\
\hline NaTPB & sodium tetraphenylborate $-\mathrm{Na}\left[\mathrm{B}\left(\mathrm{C}_{6} \mathrm{H}_{5}\right)_{4}\right]$ \\
\hline SRNL & Savannah River National Laboratory \\
\hline TPB & tetraphenylborate $-\left[\mathrm{B}\left(\mathrm{C}_{6} \mathrm{H}_{5}\right)_{4}\right]^{-}$ \\
\hline WPTS & Waste Processing Technology Section \\
\hline $95 \%$ confidence level & 95 out 100 chances the mean value will lie in this interval \\
\hline Std Dev & The length of the measuring interval or precision \\
\hline
\end{tabular}


WSRC-TR-2005-00358, REV 0

\subsection{EXECUTIVE SUMMARY}

Personnel analyzed Tank 48H sample taken on March 6, 2005, for chemical and radiological constituents. This report documents the analytical results and analysis of this data. A comparison of the results with the data from other reports (CBU-PIT-2005-00046 and CBU-PIT-2005-00066) revealed the data is consistent.

- The measured potassium tetraphenylborate (KTPB) solid concentration is $2.01 \pm 0.21 \mathrm{wt} \%$.

- The calculated monosodium titanate (MST) concentration is $0.15 \pm 0.01 \mathrm{wt} \% \mathrm{MST}$.

- The measured insoluble solids content was $3.05 \pm 0.16 \mathrm{wt} \%$. Both KTPB and MST contributed to $70 \%$ of the insoluble solids concentration. This insoluble solids content result is higher than previous Tank $48 \mathrm{H}$ analyses $(2.18 \pm 0.6)$.

- The free hydroxide concentration in the Tank $48 \mathrm{H}$ filtrate sample $(1.34 \pm 0.01 \mathrm{M})$ is greater than the Tank $48 \mathrm{H}$ limit $(1.0 \mathrm{M})$. This is an increase of $0.55 \mathrm{M}$ since the September 2003 sample due to the addition of 6,424 gallons of $50 \mathrm{wt} \%$ sodium hydroxide to Tank $48 \mathrm{H}$. ${ }^{1}$

- The soluble potassium content in the filtrate continues to follow a linear trend, which began in 1995 showing a slow radiolytic decomposition of the tetraphenylborate solids.

- The measured ${ }^{137} \mathrm{Cs}$ concentration is $7.53 \mathrm{E}+08 \pm 1.07 \mathrm{E}+07 \mathrm{dpm} / \mathrm{mL}(1.28 \mathrm{Ci} / \mathrm{gallon}$ or 313,866 curies of ${ }^{137} \mathrm{Cs}$ ) in the slurry which is lower than the expected $1.72 \mathrm{Ci} /$ gal (or 409,000 curies of ${ }^{137} \mathrm{Cs}$ ). The filtrate ${ }^{137} \mathrm{Cs}$ concentration is $3.0 \mathrm{E}+07 \pm 6.0 \mathrm{E}+04 \mathrm{dpm} / \mathrm{mL}$. This result is consistent with previous results. The filtrate ${ }^{137} \mathrm{Cs}$ does not follow a linear trend with time. Significant analytical data is summarized in Table 1.

Table 1 - Summary of Significant Tank 48H Sample Results

\begin{tabular}{|c|c|c|c|}
\hline Analyte & Slurry & Supernate & Source \\
\hline Volume, gal & 242,190 & $\mathrm{~N} / \mathrm{A}$ & Tank 48H \\
\hline Density, $\mathrm{g} / \mathrm{mL}$ & 1.165 & 1.14 & Density \\
\hline Total Solids, wt \% & 20.19 & 17.68 & Solids \\
\hline Total Insolubles, wt \% & 3.05 & NM & Calculation \\
\hline KTPB, wt \% & 2.01 & $<0.001$ & HPLC \\
\hline MST solids, wt $\%$ & 0.15 & $(<0.15 \mathrm{mg} / \mathrm{L})$ & ICP-ES \\
\hline \multicolumn{4}{|l|}{ Metals } \\
\hline Sodium, M & NM & 3.82 & ICP-ES \\
\hline Potassium, M & 0.068 & 0.006 & $\mathrm{AA}$ \\
\hline \multicolumn{4}{|l|}{ Anions } \\
\hline Free Hydroxide, M & NM & 1.34 & Titration \\
\hline Carbonate, $\mathrm{M}$ & $\mathrm{NM}$ & $0.385^{*}$ & Titration \\
\hline Nitrite, $\mathrm{M}$ & NM & 0.516 & Anion \\
\hline Nitrate, $\mathrm{M}$ & NM & 0.23 & Anion \\
\hline \multicolumn{4}{|l|}{ RadChem } \\
\hline${ }^{137} \mathrm{Cs}, \mathrm{dpm} / \mathrm{mL}$ & $7.53 \mathrm{E}+08$ & $3.0 \mathrm{E}+07$ & RadChem \\
\hline
\end{tabular}


WSRC-TR-2005-00358, REV.0

\subsection{INTRODUCTION}

Due to the need for additional HLW storage, successful disposition of the material in Tank 48H and return of the tank to routine service are two critically needed activities. ${ }^{2}$ As an initial step in the process, SRNL compositionally characterized the components of the Tank 48H slurry. Previously, a Tank 48H slurry sample was collected on August 23, 2004 (HTF-E-04-049 and HTF-E-04-050). ${ }^{3}$ The August 23, 2004 sample contained approximately 2 Liters of Tank 48H slurry. In December 7, 2004, Tank farm personnel added 3,019 gallons of $50 \mathrm{wt} \%$ caustic solution to Tank $48 \mathrm{H}$. On March 6, 2005, about of 4L of slurry was pulled from Tank $48 \mathrm{H}$ sample using a new 4.2 L sampler and sent to SRNL. Part of this sample was used for saltstone aggregation studies. The remaining Tank $48 \mathrm{H}$ sample was placed in a carboy for future analysis. Small portions of this sample were analyzed and the results are reported in this document.

This document provides the chemical and radiological characterization of a Tank $48 \mathrm{H}$ slurry sample as defined in the Technical Task Request Plan ${ }^{4}$ and task technical and quality assurance plan. At the time of the sampling, the Tank 48H volume was 242,190 gallons (69 inches from the bottom of the tank) and the pumps were ran for 27 hours prior to sampling. The sample was collected within approximately 10 minutes of pump shutdown. A description of the sampler and method is given in Appendix A. ${ }^{6}$ This report compares results with those reported elsewhere (WSRC-TR-2004-00514 [HTF-E-04-049 and HTF-E-04-050] analysis) ${ }^{3}$, CBU-PIT-2005-00066 [Tank 48 Best Estimate Chemical Characterization as of March 17, 2005] ${ }^{7}$ and CBU-PIT-200500046 [Tank 48 Radionuclide Characterization to Support Material Disposition] ${ }^{8}$ ). Since there was addition of 3,019 gallons of $50 \mathrm{wt} \%$ caustic solution to Tank $48 \mathrm{H}$ after issuing the WSRCTR-2004-00514 characterization report, the data from WSRC-TR-2004-00514 needs to be adjusted by dividing the results by a factor of 1.013. This adjustment is necessary to ensure meaningful comparison between data reported here and that reported in WSRC-TR-2004-00514 (or vise versa the results in this report must be increased by $1 \%$ for comparison with the WSRCTR-2004-00514 report). This adjustment factor (1.013) reflects the dilution effect resulting from the addition of 3,109 gallons of caustic solution (where the adjustment factor $1.013=1+$ volume of caustic added/T48H volume before addition).

\subsection{EXPERIMENTAL DETAILS}

Operations collected and shipped the Tank $48 \mathrm{H}$ sample to SRNL. Personnel placed the sample holder (HTF-E-05-021) into the shielded cells on March 6, 2005. Technicians emptied the sample vessels on March 9, 2005 by pumping the contents of the sampler holder into a calibrated 15-L polypropylene carboy using a peristaltic pump with $1 / 4$ inch Tygon ${ }^{\circledR}$ tubing. The sampler holders were sealed after the transfer.

\subsection{PREPARATION OF SLURRY SAMPLES}

Personnel diluted the slurry samples with deionized water as required for analyses. The slurry samples were analyzed in duplicate. A portion of the dried slurry was fused with sodium peroxide at $675{ }^{\circ} \mathrm{C}$. The resulting fused mass was digested with stock nitric acid and then diluted with deionized water. This method oxidizes all of the organics in the sample. This procedure utilizes more reagents and therefore results to higher dilution than other digestion methods previously used. Some filtrate samples were diluted with $0.1 \mathrm{M}$ nitric acid. 
WSRC-TR-2005-00358, REV 0

Table 2. Analysis of Tank $48 \mathrm{H}$ Slurry Samples

\begin{tabular}{|c|c|c|c|c|c|}
\hline Analysis & Samples & $\begin{array}{l}\text { Sample } \\
\text { Volume, } \\
\text { mL }\end{array}$ & $\begin{array}{c}\text { Dilution } \\
\text { Volume, } \mathbf{m L}\end{array}$ & Diluent & $\begin{array}{c}\text { Tk } 48 \\
\text { Volume, } \\
\text { mL }\end{array}$ \\
\hline GAMMA SPEC (Cs-137) & 3 & 0.1 & \multirow{5}{*}{\multicolumn{2}{|c|}{$\begin{array}{l}3 \text { samples and a blank } \\
\text { digested in Cells, then split } \\
\text { into sub-samples for analysis }\end{array}$}} & 0.3 \\
\hline CVAA HG & 3 & 20 & & & 3 \\
\hline RAD K, Hg by AA & 3 & 20 & & & 3 \\
\hline $\begin{array}{l}\text { RAD ICP-ES (Na, K, Ti, B, } \\
\mathrm{Si}, \mathrm{Cu}, \mathrm{Fe}, \mathrm{RCRA} \text { metals) }\end{array}$ & 3 & 1 & & & 3 \\
\hline $\begin{array}{l}\text { RADICPMS (fission } \\
\text { products, actinides, noble } \\
\text { metals) }\end{array}$ & 3 & 1 & & & 3 \\
\hline VOA (Benzene) & 3 & 0.1 & 9.9 & DI Water & 0.3 \\
\hline $\begin{array}{l}\text { SVOA (TPB } \\
\text { decomposition products) }\end{array}$ & 3 & 0.1 & 9.9 & DI Water & 0.3 \\
\hline Total Solids & 3 & 3 & 0 & None & 9 \\
\hline Density & 3 & 2 & 0 & None & 6 \\
\hline HPLC & 3 & 2 & 8 & DI Water & 6 \\
\hline Gamma Spec $\left(\mathrm{Cs}^{137}\right)$ & 3 & 0.1 & 0 & None & 0.3 \\
\hline
\end{tabular}

\subsection{PREPARATION OF FILTERED SAMPLES}

Personnel filtered approximately $60 \mathrm{~mL}$ of slurry to produce approximately $50 \mathrm{~mL}$ of filtrate for analysis. Technicians moved some of the slurry from the 4-L carboy into a $100 \mathrm{~mL}$ polybottle. The contents of the polybottle was well mixed by vigorously shaking and through the use of a magnetic stirrer. A portion of the mixed slurry was removed and filtered using a $0.45 \mu \mathrm{m}$ supported acrylic copolymer disc filter. They prepared sub-samples from this filtrate without dilution and submitted them for analysis as summarized in Table 3.

Table 3. Listing of Requested Filtrate Analyses

\begin{tabular}{|c|c|c|c|c|c|}
\hline \multirow{2}{*}{ Analysis } & \multirow[b]{2}{*}{ Samples } & \multirow[b]{2}{*}{$\begin{array}{c}\text { Sample } \\
\text { Volume, } \\
\text { mL }\end{array}$} & \multirow[b]{2}{*}{$\begin{array}{c}\text { Dilution } \\
\text { Volume, } \\
\text { mL }\end{array}$} & \multirow[b]{2}{*}{ Diluent } & \multirow[b]{2}{*}{$\begin{array}{c}\text { Tk } 48 \\
\text { Volume, } \\
\text { mL }\end{array}$} \\
\hline & & & & & \\
\hline GAMMA SPEC & 2 & 0.1 & 9.9 & $\begin{array}{l}0.1 \mathrm{M} \\
\mathrm{HNO}_{3} \\
\end{array}$ & 0.2 \\
\hline HPLC (TPB, 3PB, 2PB, 1PB, \& phenol) & 2 & 2 & 0 & None & 4 \\
\hline CARBONATE & 2 & 1 & 0 & None & 2 \\
\hline $\begin{array}{l}\text { TITRATION BASE/OH/OTHER } \\
\text { BASE (EXCLUDING CO3) }\end{array}$ & 2 & 1 & 0 & None & 2 \\
\hline $\begin{array}{l}\text { IC ANIONS [F-, } \mathrm{Cl}^{-}, \mathrm{HCO}_{2}^{-},(\mathrm{C} 2 \mathrm{O} 4) 2-, \\
\text { (SO4)2-, (NO3)-, (NO2)-], }\end{array}$ & 2 & 1 & 0 & None & 2 \\
\hline RAD ICP-ES (Na, K, Ti, B, Si) & 2 & 2 & 8 & $\begin{array}{l}0.1 \mathrm{M} \\
\mathrm{HNO}_{3}\end{array}$ & 4 \\
\hline RAD ICP-MS (actinides) & 2 & 2 & 8 & $\begin{array}{l}0.1 \mathrm{M} \\
\mathrm{HNO}_{3} \\
\end{array}$ & 4 \\
\hline DISSOLVED SOLIDS & 2 & 1 & 0 & None & 2 \\
\hline Density & 2 & 5 & 0 & None & 10 \\
\hline
\end{tabular}




\subsection{IN-CELL ANALYSES}

Personnel performed two analyses, each in duplicate, in the shielded cells to minimize the dose to analytical personnel. Personnel determined both the density of the slurry and the total and insoluble solids concentration of the slurry gravimetrically. Note that insoluble solids are defined as those solids that can be removed by filtration, and soluble solids as those solids that can not be filtered, and total solids as sum of the two. These results are reported in wt \% solids on a slurry basis.

Personnel gravimetrically determined the density of the slurry at ambient cell temperature $\left(24{ }^{\circ} \mathrm{C}\right)$ using $2 \mathrm{~mL}$ Class A micro-volumetric flasks.

Technicians gravimetrically determined the total solids by drying portions of the sample to constant weight at $100 \pm 5^{\circ} \mathrm{C}$. They used duplicate analysis of a nominal $15 \mathrm{wt} \% \mathrm{NaCl}$ standard, slurry sample and the filtered filtrate to measure the total solids and dissolved solids in the Tank 48H material. Technicians pre-weighed clean dry Pyrex ${ }^{\mathrm{TM}}$ beakers for each analysis. Personnel mixed the samples thoroughly, removed $\sim 3 \mathrm{~mL}$ aliquots, and delivered each aliquot into each beaker (i.e., $3 \mathrm{~mL}$ of the 15 wt $\% \mathrm{NaCl}$ standard into beakers $1,2,3 \mathrm{~mL} ; 3 \mathrm{~mL}$ of Tank $48 \mathrm{H}$ slurry sample into beakers $4-6$ and, and $3 \mathrm{~mL}$ of Tank $48 \mathrm{H}$ filtrate into beakers 7-9). Personnel weighed each beaker with sample immediately after addition then proceeded to dry the samples in a $100-115^{\circ} \mathrm{C}$ oven for 8 hours. Samples were allowed to cool in a dessicator for $15 \mathrm{~min}$ before additional-weighing. Technicians repeated the drying cycle 3 additional times to ensure complete sample drying.

\subsection{EXPERIMENTAL RESULTS}

ADS personnel completed the analyses between April 12 and July 25, 2005. The slurry results are generally reported in units of $\mathrm{mg} / \mathrm{L}$ of slurry and the filtrate results in units of $\mathrm{mg} / \mathrm{L}$ filtrate. To convert the filtrate results to a slurry bases, the filtrate data is multiplied by a factor of $0.957^{*}$. This correction is necessary to compare the filtrate and slurry results to determine the insoluble solids concentration. The results are reported in this section and discussed in detail in Section 5.0, Analysis of Data.

\subsection{ADS SLURRY SAMPLE RESULTS}

ADS personnel analyzed the filtrate data in duplicate and the digested slurry data in triplicate. When outliers were detected, we reported the average or the value (in the case of duplicate samples) of the remaining sample. We report the analytical data together with the one standard deviation $(1 \sigma)$ uncertainty.

\subsubsection{Radionuclide Composition}

Many of the radioisotopes are measured using ICP-MS methods. However, personnel determined

${ }^{137} \mathrm{Cs}$ by radio-counting analyses for the Tank $48 \mathrm{H}$ slurry - see Table 4 . The major radiation hazard in Tank $48 \mathrm{H}$ comes from the ${ }^{137} \mathrm{Cs}$, with a concentration of $1.28 \mathrm{Ci} / \mathrm{gallon}(2004$ measurement reported a value of $1.54 \mathrm{Ci} /$ gallon at total volume of 239,031 gallons and 2003 measurement reported a value of $1.72 \mathrm{Ci} / \mathrm{gal}$ ). This is a $17 \%$ decrease in value relative to the previous measurement and $25 \%$ decrease from the 2003 measurement of $1.72 \mathrm{Ci} / \mathrm{gal}$. The current

\footnotetext{
* This factor is the ratio of filtrate mass $(\mathrm{mg} / \mathrm{L})$ to slurry mass $(\mathrm{mg} / \mathrm{L})$. It is calculated by the following formula: filtrate correction factor $=$ density slurry/density filtrate* $(1$-insoluble solids $)=1.165 / 1.18^{*}(1-0.0305)=0.957$
} 
value listed on CBU report (CBU-PIT-2005-00046) is $1.72 \mathrm{Ci} / \mathrm{gal}$. As described in section 4.2.4., the ${ }^{137} \mathrm{Cs}$ concentration in the filtrate in this and previous study are similar. The current measurement estimates a total of 310,003 curies of ${ }^{137} \mathrm{Cs}$ in Tank $48 \mathrm{H}$ (current volume is 242,190 gallons).

Table 4 - Tank 48H Slurry Radiation Chemistry Analytical Results. Reported value for HTF-E-05-021 are averages of three measurements.

\begin{tabular}{|c|c|c|c|}
\hline Radionuclide & $\begin{array}{c}\text { Sample } \\
\text { HTF-E-05-021 } \\
(\mathrm{dpm} / \mathrm{mL} \text { slurry })\end{array}$ & $\begin{array}{c}\text { Sample } \\
\text { HTF-E-04-049 and } \\
\text { HTF-E-0050 } \\
(\mathrm{dpm} / \mathrm{mL} \text { slurry })\end{array}$ & $\begin{array}{c}\text { CBU-PIT-2005-00046 } \\
\text { (dpm/mL slurry) }\end{array}$ \\
\hline $\mathrm{Cs}^{137}$ & $7.53 \pm 0.25 \mathrm{E}+08$ & $9.05 \pm 0.11 \mathrm{E}+08$ & $1.01 \mathrm{E}+09$ \\
\hline
\end{tabular}

\subsubsection{Inductively Coupled Spectroscopy - Emission Spectroscopy for Slurry Samples}

Personnel determined the elemental composition (in $\mathrm{g} / \mathrm{L}$ of slurry) of the digested slurry by ICP-ES. The digestion method used (sodium peroxide fusion) masked the true concentration of sodium in the slurry (previous measurement of sodium measured 3.26 M). The ICP-ES results from another report (HTF-E-05-021) are shown in Table 5. The major constituents in the slurry include $\mathrm{Na}, \mathrm{K}, \mathrm{Al}, \mathrm{Fe}$ and $\mathrm{B}$. Aluminum, iron and boron are present in appreciable levels. Approximately equal concentrations of aluminum, manganese, chromium, and titanium were found between this study and previous results. Note that the iron concentration is higher than in previous measurement. The sludge is an aggregate of metal hydroxide/oxide compounds (or particles) and it is possible, through extensive mixing, to separate or disrupt aggregates of particles. Hematite is sub-micron size iron particles which will remain suspended for long times in slurries. The potassium concentration, determined by ICPE-S, measured $5.15 \mathrm{~g} / \mathrm{L}_{\text {slurry. }}$ We suspected this value was too high. This reported value for potassium is not in agreement with the independent measurements obtained by Atomic Absorption $(2.3 \pm 0.04 \mathrm{~g} / \mathrm{L})$ as described in a subsequent sections. Previous measurements for two earlier samples collected from the tank report a value similar to the AA result $(2.38 \mathrm{~g} / \mathrm{L})$. Discussions with both the AA and ICP-ES chemists revealed that the preferred (more accurate and precise) way to measure $\mathrm{K}$ is with AA. Elements measured below method detection limits include $\mathrm{Ag}, \mathrm{Cd}, \mathrm{Gd}, \mathrm{La}, \mathrm{Ni}, \mathrm{Pb}$, and $\mathrm{V}$. Their detection limits are listed in Table 5. 
Table 5. The ICP-ES results for the digested slurry from the HTF-E-05-21 sample. All units are given in $\mathrm{mg} / \mathrm{L}$ slurry

\begin{tabular}{|c|c|c|c|c|}
\hline Component & Average & Std. Dev. & $\begin{array}{c}\text { Sample } \\
\text { HTF-E-04-049 and } \\
\text { HTF-E-0050 }\end{array}$ & $\begin{array}{c}\text { CBU-PIT-2005- } \\
00066\end{array}$ \\
\hline $\mathrm{Ag}$ & $<0.01$ & - & & \\
\hline $\mathrm{Al}$ & 2014 & 32 & 2240 & 2240 \\
\hline $\mathrm{B}$ & 867 & 24 & 1030 & 987 \\
\hline $\mathrm{Ba}$ & $<0.008$ & - & 2.52 & 3.47 \\
\hline $\mathrm{Be}$ & NM & - & & \\
\hline $\mathrm{Ca}$ & 43 & 47 & 21.4 & 19.7 \\
\hline $\mathrm{Cd}$ & $<0.017$ & - & NR & 0.022 \\
\hline $\mathrm{Ce}$ & 5 & 8 & 7 & NR \\
\hline $\mathrm{Cr}$ & 70 & 5 & 51 & 46.6 \\
\hline $\mathrm{Cu}$ & 4 & 0 & 3 & 2.97 \\
\hline $\mathrm{Fe}$ & 169 & 29 & 43 & 53.9 \\
\hline $\mathrm{Gd}$ & $<0.01$ & - & NR & NR \\
\hline $\mathrm{K}$ & $5155^{\#}$ & 366 & 2380 & 2570 \\
\hline $\mathrm{La}$ & $<0.032$ & - & NR & NR \\
\hline $\mathrm{Li}$ & $<0.026$ & - & NR & NR \\
\hline $\mathrm{Mg}$ & 19 & 4 & 18.5 & 20.2 \\
\hline $\mathrm{Mn}$ & 6 & 0 & 6.38 & 7.82 \\
\hline Mo & $<0.053$ & - & 13.3 & NR \\
\hline $\mathrm{Ni}$ & $<0.015$ & - & NR & NR \\
\hline $\mathrm{P}$ & 129 & 13 & 207 & NR \\
\hline $\mathrm{Pb}$ & $<0.283$ & - & NR & NR \\
\hline $\mathrm{S}$ & 378 & 90 & 245 & NR \\
\hline $\mathrm{Sb}$ & $<0.042$ & - & 11.5 & NR \\
\hline $\mathrm{Si}$ & 125 & 8 & 106 & NR \\
\hline $\mathrm{Sn}$ & $<0.11$ & - & 22.1 & NR \\
\hline $\mathrm{Sr}$ & 9 & 9 & 5.29 & NR \\
\hline $\mathrm{Ti}$ & 826 & 14 & 840 & NR \\
\hline $\mathrm{U}$ & 7 & 12 & 17.6 & NR \\
\hline $\mathrm{V}$ & $<0.007$ & - & NR & NR \\
\hline $\mathrm{Zn}$ & 5 & 1 & 12 & NR \\
\hline $\mathrm{Zr}$ & 1.47 & 0.13 & NR & NR \\
\hline \multicolumn{5}{|c|}{$\begin{array}{l}\mathrm{NM}=\text { Not Measured } \\
\mathrm{NR}=\text { Not Reported } \\
\text { *Duplicate measured identical values } \\
{ }^{\#} \text { This value is twice the AA value. This report will use AA value }\end{array}$} \\
\hline
\end{tabular}




\subsubsection{Inductively Coupled Spectroscopy - Mass Spectroscopy for Slurry Samples}

SRNL performed three analyses of the Tank $48 \mathrm{H}$ slurry for actinides. The replicate samples showed excellent precision (Table 6). ${ }^{240} \mathrm{Pu},{ }^{241} \mathrm{Am},{ }^{243} \mathrm{Am}$, and ${ }^{244} \mathrm{Cm}$ (LOD for these elements was less than $0.09 \mathrm{mg} / \mathrm{L}_{\text {slurry }}$ are all less than the detection limits. ${ }^{238} \mathrm{Pu}$ can not be detected by this analytical method. No ${ }^{239} \mathrm{Pu}$ was detected in HTF-E-05-021(LOD $\left.=0.045 \mathrm{mg} / \mathrm{L}\right)$. The limit of detection for ${ }^{239} \mathrm{Pu}$ is above the results previously published.

Table 6. The actinide results for the digested slurry from the HTF-E-0521 sample. The fourth column shows the actinide data from previous measurements.

\begin{tabular}{|c|c|c|c|}
\hline Component & $\begin{array}{c}\text { Average } \\
(\mathrm{mg} / \mathrm{L} \text { slurry })\end{array}$ & $\begin{array}{c}\text { Std Dev. } \\
(\mathrm{mg} / \mathrm{L} \text { slurry })\end{array}$ & $\begin{array}{c}\text { CBU-PIT- } \\
2005-00046 \\
(\mathrm{mg} / \mathrm{L} \text { slurry })\end{array}$ \\
\hline $99(\mathrm{Tc})$ & $1.23 \mathrm{E} 0$ & 0.08 & NM \\
\hline $237(\mathrm{~Np})$ & $1.73 \mathrm{E}-1$ & 0.040 & $2.83 \mathrm{E}-1$ \\
\hline $239(\mathrm{Pu})$ & $<0.045 \mathrm{mg} / \mathrm{L}$ & - & $4.46 \mathrm{E}-2$ \\
\hline $233(\mathrm{U})$ & $<0.09 \mathrm{mg} / \mathrm{L}$ & - & $9.44 \mathrm{E}-2$ \\
\hline $234(\mathrm{U})$ & $2.67 \mathrm{E}-1$ & 0.012 & $4.99 \mathrm{E}-1$ \\
\hline $235(\mathrm{U})$ & $5.64 \mathrm{E}-1$ & 0.050 & $9.71 \mathrm{E}-1$ \\
\hline $236(\mathrm{U})$ & $1.25 \mathrm{E}-1$ & 0.006 & $1.48 \mathrm{E} 0$ \\
\hline $238(\mathrm{U})$ & $3.32 \mathrm{E} 0$ & 0.359 & $6.16 \mathrm{E} 0$ \\
\hline TOTAL $(\mathrm{U})$ & $4.48 \mathrm{E} 0$ & 0.36 & $6.32 \mathrm{E} 0$ \\
\hline NM = Not Measured
\end{tabular}

We analyzed a slurry sample for transition metals (i.e., $\mathrm{Ag}, \mathrm{Pd}, \mathrm{Rh}$, and $\mathrm{Ru}$ ). The elemental results of the Tank $48 \mathrm{H}$ slurry sample are presented in Table 7. Contrary to the results for HTFE-04-049 sample, our analysis found no measurable amounts of these transition metals. The concentrations of these metals ( $\mathrm{Ru}, \mathrm{Rh}$ or $\mathrm{Ag}$ ) were all below the instrument detection limit. The lower bias shown in this work may be due to the sample preparation involved. Zirconium crucibles were used for peroxide fusion leaching, which normally leads to $\mathrm{Zr}$ leaching into the sample matrix. Sodium peroxide fusion method was used to completely oxidize all of the organics. Analytical Division personnel used large amounts of water for dilution and thus raising the limit of detection above the limits previously published. Zirconium interference in the ICPMS data masked Pd metal detection. Mercury concentration was less than $0.4 \mathrm{mg} / \mathrm{L}_{\text {slurry }}(\mathrm{LOD})$. The digestion process reached at least $670^{\circ} \mathrm{C}$. At this temperature, we expect mercury to volatize. 
Table 7. List the noble metal composition of the slurry HTF-E-05-021 as determined by ICP-MS.

\begin{tabular}{|c|c|c|}
\hline Component & HTF-E-05-021 & CBU-PIT-2005-00066 \\
\hline Total $\mathrm{Cd}, \mathrm{mg} / \mathrm{L}$ & $\mathbf{1 . 4}$ E-02 & $2.16 \mathrm{E}-02$ \\
\hline Total $\mathrm{Ag}, \mathrm{mg} / \mathrm{L}$ & < Detection Limit (0.73) & $1.88 \mathrm{E}-02$ \\
\hline Total $\mathrm{Pd}, \mathrm{mg} / \mathrm{L}$ & Interference from $\mathbf{~ Z r}$ & $9.28 \mathrm{E}-02$ \\
\hline Total $\mathrm{Rh}, \mathrm{mg} / \mathrm{L}$ & < Detection Limit (0.7) & $2.30 \mathrm{E}-01$ \\
\hline Total $\mathrm{Ru}, \mathrm{mg} / \mathrm{L}$ & < Detection Limit (1.16) & $3.80 \mathrm{E}-01$ \\
\hline
\end{tabular}

\subsubsection{Atomic Absorption Spectroscopy of the Slurry}

Personnel determined the potassium content of the digested slurry by AA. The measured potassium concentration in the digested slurry is reported as $2,310 \pm 42 \mathrm{mg} / \mathrm{L}(0.06 \pm 0.001 \mathrm{M})$. This concentration is comparable to the value of $2,650 \pm 184 \mathrm{mg} / \mathrm{L}(0.068 \pm 0.0047 \mathrm{M})$ reported for HTF-E-04-049 sample. No measurable amounts of As, $\mathrm{Hg}$ and Se were detected. The LOD (limit of detection) for As, $\mathrm{Hg}$ and Se are $4.6 \mathrm{mg} / \mathrm{L}, 10.23 \mathrm{mg} / \mathrm{L}$ and $4.8 \mathrm{mg} / \mathrm{L}$, respectively. It is worth noting that this method utilizes temperatures that may lead to $\mathrm{Hg}$ volatization. Therefore, the $\mathrm{Hg}$ concentration reported here is well below the true value. 


\subsubsection{Volatile and Semi-Volatile Organic Analyses (VOA and SVOA) for Slurry Samples}

SVOA analysis is used to detect aromatic compounds. The SVOA and VOA results from the slurry sample for the HTF-E-05-021 sample are shown in Table 8. Also shown in Table 8 are the results of similar compounds in the HTF-E-04-049 and E-0050 samples. The analysis result indicates the presence of nitro-aromatic compounds and other condensed ring compounds. Although nitro-aromatic compounds are energetic, their low concentrations observed here will not result in a significant temperature rise or gas generation upon decomposition. Table 8 also shows that 1-ethyldisopropyl benzene is present. The presence of this compound is not expected nor is it predicted. This compound assignment may be an artifact of the SVOA compound identification method or additives from the sample's bottle. A more precise analytical HPLC was conducted on the HTF-E-05-021 sample and it showed no evidence of this compound or any nitrated aromatics. Volatile analysis indicates the presence of benzene in the slurry. Benzene is a byproduct from the decomposition of TPB and its degradation products.

Table 8. Results from the VOA and SVOA analysis of the slurry HTF-E-05021.

\begin{tabular}{|l|c|c|c|}
\hline \multicolumn{1}{|c|}{ Component } & $\begin{array}{c}\text { Average } \\
(\mathrm{mg} / \mathrm{L} \text { slurry })\end{array}$ & $\begin{array}{c}\text { St Dev } \\
(\mathrm{mg} / \mathrm{L} \text { slurry })\end{array}$ & $\begin{array}{c}\text { Sample HTF- } \\
\text { E-04-049 and } \\
\text { HTF-E-0050 } \\
(\mathrm{mg} / \mathrm{L})\end{array}$ \\
\hline Biphenyl & 414.6 & 105.6 & 384 \\
\hline Nitrobenzene & 180.6 & 104.4 & $<10$ \\
\hline Phenol* & 98.1 & 35.7 & 735 \\
\hline p-terphenyl & 182.0 & - & $<10$ \\
\hline 1-ethyldisopropyl benzene & 64.3 & 32.7 & $<10$ \\
\hline Nitrosobenzene & 25.3 & 5.4 & $<10$ \\
\hline Benzene & 17.9 & 1.0 & $<10$ \\
\hline *This value is not as precise as the value obtained in Table 9. \\
\hline
\end{tabular}

\subsubsection{High Performance Liquid Chromatography-Slurry Samples}

Personnel measured the concentration of tetraphenylborate and its degradation products in the HTF-E-05-021 slurry sample by HPLC. Table 9 lists the HPLC results for the slurry. The analytical method is considered more sensitive to organic anion measurement than the SVOA method. Both TPB and KTPB concentration, as shown in Table 9, are consistent with previous measurements. 
WSRC-TR-2005-00358, REV 0

Table 9. The HPLC results of HTF-E-05-021 slurry sample.

\begin{tabular}{|l|c|c|c|}
\hline Analyte & $\begin{array}{c}\text { Concentration, } \\
(\mathrm{mg} / \text { L slurry })\end{array}$ & $\begin{array}{c}\text { St. Dev, } \\
(\mathrm{mg} / \mathrm{L})\end{array}$ & $\begin{array}{c}\text { CBU-PIT-2005-00066 } \\
(\mathrm{mg} / \mathrm{L})\end{array}$ \\
\hline TPB Anion & 21,000 & 970 & 18500 \\
\hline Calculated KTPB & 23796 & - & 20761 \\
\hline 3PB & 74 & 16.5 & $<50$ \\
\hline 2PB & 142 & 19 & $<50$ \\
\hline 1PB & 151 & 7.6 & $<50$ \\
\hline Phenol & 771 & 22 & 673 \\
\hline Biphenyl & 420 & 54.3 & 632 \\
\hline NM = Not Measured & \multicolumn{3}{|l}{} \\
\hline
\end{tabular}

\subsection{FILTRATE SAMPLE RESULTS}

ADS personnel analyzed duplicate filtrate Tank $48 \mathrm{H}$ samples. Personnel removed samples of the Tank $48 \mathrm{H}$ filtrate from the cells without dilution. ADS personnel diluted the filtrate as appropriate for the analyses. We report the analytical data together with the one standard deviation $(1 \sigma)$ uncertainty. To compare the slurry results with the filtrate results, the filtrate result is multiplied by a factor of 0.957 to convert to a slurry basis. Note that a filtrate sample has been filtered to remove insoluble solids and a supernate sample has been pulled from an unslurried tank but has not been filtered. It is expected that supernate results from previous samples would have slightly higher insoluble solids concentrations since additional caustic solution was added to Tank $48 \mathrm{H}$ before the collection of the earlier samples.

\subsubsection{Anion Analysis by Ion Chromatography for Filtrate Sample}

Table 10 contains the measured values for the Tank $48 \mathrm{H}$ filtered sample. Table 10 includes the measured anion concentrations for the tank sample. Nitrate and nitrite concentrations are $0.52 \mathrm{M}$ and $0.23 \mathrm{M}$, respectively. 
Table 10. The anion composition of HTF-E-05-021 filtrate sample. The two set values are from duplicate analysis.

\begin{tabular}{|c|c|c|c|}
\hline Anion Component & $\begin{array}{c}\text { Average } \\
\text { Concentration } \\
(\mathrm{mg} / \mathrm{L})\end{array}$ & $\begin{array}{c}\text { Standard } \\
\text { Deviation } \\
(\mathrm{mg} / \mathrm{L})\end{array}$ & $\begin{array}{c}\text { CBU-PIT-2005- } \\
00066 \\
(\mathrm{mg} / \mathrm{L})\end{array}$ \\
\hline $\mathrm{F}^{-}$ & 14 & $\begin{array}{c}0 \text { (exact } \\
\text { duplicates) }\end{array}$ & $<18$ \\
\hline $\mathrm{Cl}^{-}$ & 172 & 23 & 125 \\
\hline $\mathrm{HCOO}^{-}$ & 502 & 10 & 432 \\
\hline $\mathrm{NO}_{2}{ }^{-}$ & 23750 & 350 & 21400 \\
\hline $\mathrm{NO}_{3}{ }^{-2}$ & 14250 & 150 & 13400 \\
\hline $\mathrm{PO}_{4}{ }^{2-}$ & 428 & 9 & 515 \\
\hline $\mathrm{SO}_{4}{ }^{2-}$ & 323 & 1 & 273 \\
\hline $\mathrm{C}_{2} \mathrm{O}_{4}{ }^{2-}$ & 1440 & 10 & 1080 \\
\hline
\end{tabular}

\subsubsection{High Performance Liquid Chromatography-Filtrate Sample}

ADS completed analysis of the Tank $48 \mathrm{H}$ filtrate for tetraphenylborate and 14 of its common decomposition products. Only phenol at $535 \pm 5 \mathrm{mg} / \mathrm{L}$ occur above the detection limit. TPB, $3 \mathrm{~PB}, 2 \mathrm{~PB}$, and $1 \mathrm{~PB}$ all fell below detection limits of $10 \mathrm{mg} / \mathrm{L}$ (see Table 11). Other decomposition products were below method's detections limit.

Table 11. The phenylborate composition of the filtrate as determined by HPLC (mg/L).

\begin{tabular}{|c|c|c|c|c|}
\hline Component & $1^{\text {st }}$ sample & $2^{\text {nd }}$ sample & $\begin{array}{c}\text { Average or } \\
\text { Limit of } \\
\text { Detection }\end{array}$ & $\begin{array}{c}\text { CBU-PIT- } \\
2005-00066\end{array}$ \\
\hline TPB & $<10$ & $<10$ & $<10$ & $<10$ \\
\hline 3 PB & $<10$ & $<10$ & $<10$ & $<10$ \\
\hline 2 PB & $<10$ & $<10$ & $<10$ & $<10$ \\
\hline 1PB & $<10$ & $<10$ & $<10$ & $<10$ \\
\hline phenol & 531 & 538 & $534.5 \pm 5$ & 706 \\
\hline
\end{tabular}

\subsubsection{Wet Chemistry-Filtrate Sample}

ADS personnel analyzed the filtrate samples using titration methods and density measurements. The total base concentration is $2.48 \pm 0.05 \mathrm{M}$ and the free hydroxide is $1.34 \pm 0.01 \mathrm{M}$. The concentration of other bases is $0.172 \pm 0.02 \mathrm{M}$ and carbonate concentration is $0.385 \pm 0.01 \mathrm{M}$. Table 12 lists the titration results for the HTF-E-05-021 sample.

The free hydroxide concentration at $1.34 \mathrm{M}$ has increased since the September 2003 sampling $(0.790 \mathrm{M})$ due to the addition of sodium hydroxide in October 2003 and December 2004.

ADS measured the Tank $48 \mathrm{H}$ filtrate density as $1.14 \pm 0.01 \mathrm{~g} / \mathrm{mL}$.

The dissolved solids concentration of the Tank $48 \mathrm{H}$ filtrate was $17.68 \% \pm 0.14 \mathrm{wt} \%$. The dissolved solids concentration of the August 24,2004 filtrate was $16.28 \pm 0.27 \mathrm{wt} \%$. The dissolved solids concentration of the June 3, 2003 and September 23, 2003 filtrate was $16.6 \mathrm{wt} \%$. 
Table 12. The base composition of HTF-E-05-021 filtrate sample. The two set values are from duplicate sample analysis. Value in parenthesis represents 1 sigma uncertainty.

\begin{tabular}{|c|c|c|c|c|}
\hline Component & (Molar) & (Molar) & $\begin{array}{l}\text { Average } \\
\text { (Molar) }\end{array}$ & $\begin{array}{c}\text { Sample } \\
\text { HTF-E-04-049 and } \\
\text { HTF-E-0050 } \\
\text { (Molar) }\end{array}$ \\
\hline Total Base & $\begin{array}{c}2.52 \\
( \pm 10 \%)\end{array}$ & $\begin{array}{c}2.45 \\
( \pm 10 \%)\end{array}$ & $2.485 \pm 0.05$ & 2.04 \\
\hline Free $\mathrm{OH}^{-}$ & $\begin{array}{c}1.35 \\
( \pm 10 \%) \\
\end{array}$ & $\begin{array}{c}1.33 \\
( \pm 10 \%)\end{array}$ & $1.34 \pm 0.014$ & 1.155 \\
\hline $\begin{array}{c}\text { Other Base } \\
\text { (excluding } \\
\mathrm{CO}_{3}{ }^{2-} \text { ) } \\
\end{array}$ & $\begin{array}{c}0.156 \\
( \pm 25 \%)\end{array}$ & $\begin{array}{c}0.188 \\
( \pm 25 \%)\end{array}$ & $0.172 \pm 0.023$ & 0.185 \\
\hline $\mathrm{CO}_{3}{ }^{2-}$ & $\begin{array}{c}0.389 \\
( \pm 25 \%) *\end{array}$ & $\begin{array}{c}0.382 \\
( \pm 25 \%)^{*}\end{array}$ & $\begin{array}{c}0.3855 \pm \\
0.005\end{array}$ & 0.492 \\
\hline
\end{tabular}

\subsubsection{Radionuclide Composition for Filtrate Sample}

ADS personnel analyzed the filtered sample using radio-analytical methods. Cesium $\left({ }^{137} \mathrm{Cs}\right)$ is the major radioactive analyte in the filtrate at a concentration of $3.0 \pm 0.4 \mathrm{E} 7 \mathrm{dpm} / \mathrm{mL}$. Table 13 summarizes the radionuclide concentrations. Other isotopes were not analyzed. Table 14 provides a comparison with previous sample results.

Personnel analyzed the filtrate radionuclide content by ICP-MS. Table 14 lists the lanthanide and actinide concentration for the HTF-E-05-021 sample.

Table 13. Tank $48 \mathrm{H}$ Filtrate radiation chemistry data.

\begin{tabular}{|l|c|c|}
\hline Analyte & $\begin{array}{c}\text { Sample } \\
\text { HTF-E-005-021 }\end{array}$ & $\begin{array}{c}\text { CBU-PIT- } \\
2005- \\
00046\end{array}$ \\
\hline${ }^{137} \mathrm{Cs}(\mathrm{dpm} / \mathrm{mL})$ & $3.0 \pm 0.4 \mathrm{E}+07$ & $2.76 \mathrm{E}+07$ \\
\hline
\end{tabular}


Table 14. The ICP-MS results of HTF-E-05-021 filtrate sample. The two set values are from duplicate sample analysis.

\begin{tabular}{|c|c|c|c|c|}
\hline Actinide & $\begin{array}{c}1^{\text {st }} \text { sample } \\
(\mathrm{mg} / \mathrm{L})\end{array}$ & $\begin{array}{c}2^{\text {nd }} \text { Sample } \\
(\mathrm{mg} / \mathrm{L})\end{array}$ & Average $(\mathrm{mg} / \mathrm{L})$ & $\begin{array}{c}\text { CBU-PIT-2005- } \\
00046(\mathrm{mg} / \mathrm{L})\end{array}$ \\
\hline${ }^{232} \mathrm{Th}$ & $1.952 \mathrm{E}-2$ & - & $1.952 \mathrm{E}-2 \pm 0$ & NM \\
\hline${ }^{233} \mathrm{U}$ & $1.035 \mathrm{E}-2$ & $1.009 \mathrm{E}-2$ & $1.022 \mathrm{E}-2 \pm 0.18 \mathrm{E}-3$ & $4.94 \mathrm{E}-2$ \\
\hline${ }^{234} \mathrm{U}$ & $7.295 \mathrm{E}-2$ & $6.960 \mathrm{E}-2$ & $7.128 \mathrm{E}-2 \pm 2.4 \mathrm{E}-3$ & $3.58 \mathrm{E}-1$ \\
\hline${ }^{235} \mathrm{U}$ & $1.411 \mathrm{E}-1$ & $1.450 \mathrm{E}-1$ & $1.431 \mathrm{E}-1 \pm 2.8 \mathrm{E}-3$ & $5.74 \mathrm{E}-1$ \\
\hline${ }^{236} \mathrm{U}$ & $3.050 \mathrm{E}-2$ & $3.150 \mathrm{E}-2$ & $3.100 \mathrm{E}-2 \pm 0.7 \mathrm{E}-3$ & $1.41 \mathrm{E} 0$ \\
\hline${ }^{237} \mathrm{~Np}$ & $1.862 \mathrm{E}-2$ & $1.851 \mathrm{E}-2$ & $1.856 \mathrm{E}-2 \pm 0.1 \mathrm{E}-3$ & $5.39 \mathrm{E}-2$ \\
\hline${ }^{238} \mathrm{U}$ & $8.453 \mathrm{E}-1$ & $8.054 \mathrm{E}-1$ & $8.253 \mathrm{E}-1 \pm 28 \mathrm{E}-3$ & $3.62 \mathrm{E} 0$ \\
\hline Total U & - & - & $1.10 \mathrm{E} 0$ & $6.01 \mathrm{E} 0$ \\
\hline
\end{tabular}

\subsubsection{Inductively Coupled Spectroscopy - Emission Spectroscopy-Filtrate Sample}

ADS determined the elemental composition of the filtrate by the ICP-ES method. The major constituents found in the filtrate included $\mathrm{Na}$ and $\mathrm{B}$, as shown in Table 15. The element sodium is present in the highest concentration at $3.82 \mathrm{M}$. Boron is present in appreciable levels, too. Elements measured below instrument detection limits include $\mathrm{Ag}, \mathrm{Ba}, \mathrm{Cd}, \mathrm{Ce}, \mathrm{Fe}, \mathrm{Gd}, \mathrm{La}, \mathrm{Li}$, $\mathrm{Mg}, \mathrm{Mn}, \mathrm{Ni}, \mathrm{Pb}, \mathrm{Sn}, \mathrm{Ti}, \mathrm{U}$, and $\mathrm{Zr}$ (LOD values for these elements are listed in Table 15). Table 15 provides the elemental results of the Tank $48 \mathrm{H}$ filtrate samples. One of the samples analyzed showed low $\mathrm{K}$ concentration. We attribute this low $[\mathrm{K}]$ value to possible over dilution with water. Table 16 provides a comparison with historical data. Inspection of Table 16 reveals higher $\mathrm{Na}$ and $\mathrm{B}$ concentrations. This we attribute to additions to Tank $48 \mathrm{H}$ and to TPB decomposition. 
Table 15. The cation composition of HTF-E-05-021 filtrate sample as determined by ICP-ES. The two set values are from duplicate sample analysis.

\begin{tabular}{|c|c|c|c|c|}
\hline $\begin{array}{c}\text { Cation } \\
\text { Component }\end{array}$ & $\begin{array}{c}1^{\text {st }} \text { Sample } \\
(\mathrm{mg} / \mathrm{L})\end{array}$ & $\begin{array}{c}2^{\text {nd }} \text { Sample } \\
(\mathrm{mg} / \mathrm{L})\end{array}$ & $\begin{array}{c}\text { Average }(\mathrm{mg} / \mathrm{L}) \\
\text { or LOD }\end{array}$ & $\begin{array}{c}\text { Standard } \\
\text { Deviation }(\mathrm{mg} / \mathrm{L}) \\
\end{array}$ \\
\hline $\mathrm{B}^{+*}$ & 466.7 & 453.3 & 460 & 9.47 \\
\hline $\mathrm{K}^{+}$ & $<39$ & 266.7 & 266.7 & - \\
\hline $\mathrm{Na}^{+}$ & 85848 & 89950 & 87899 & 2948 \\
\hline $\mathrm{Si}^{4+}$ & $<125$ & $<125$ & $<125$ & - \\
\hline $\mathrm{Ti}^{4+}$ & $<1$ & $<1$ & $<1$ & - \\
\hline $\mathrm{Al}$ & 2344 & 2272 & 2309 & 50.7 \\
\hline $\mathrm{Si}$ & $<125$ & $<125$ & $<125$ & - \\
\hline $\mathrm{Ag}$ & $<3$ & $<3$ & $<3$ & - \\
\hline $\mathrm{Ba}$ & $<6$ & $<6$ & $<6$ & - \\
\hline $\mathrm{Cd}$ & $<1$ & $<1$ & $<1$ & - \\
\hline $\mathrm{Ce}$ & $<35$ & $<35$ & $<35$ & - \\
\hline $\mathrm{Fe}$ & $<3$ & $<3$ & $<3$ & - \\
\hline $\mathrm{Cu}$ & $<3$ & $<3$ & $<3$ & - \\
\hline $\mathrm{Gd}$ & $<4$ & $<4$ & $<4$ & - \\
\hline $\mathrm{La}$ & $<13$ & $<13$ & $<13$ & - \\
\hline $\mathrm{Li}$ & $<12$ & $<12$ & $<12$ & - \\
\hline $\mathrm{Mg}$ & $<1$ & $<1$ & $<1$ & - \\
\hline $\mathrm{Mn}$ & $<1$ & $<1$ & $<1$ & - \\
\hline $\mathrm{Ni}$ & $<10$ & $<10$ & $<10$ & - \\
\hline $\mathrm{Pb}$ & $<196$ & $<196$ & $<196$ & - \\
\hline $\mathrm{Sn}$ & $<77$ & $<77$ & $<77$ & - \\
\hline $\mathrm{Ti}$ & $<1$ & $<1$ & $<1$ & \\
\hline $\mathrm{U}$ & $<50$ & $<50$ & $<50$ & \\
\hline $\mathrm{Zr}$ & $<2$ & $<2$ & $<2$ & \\
\hline
\end{tabular}


WSRC-TR-2005-00358, REV 0

Table 16. Comparison between HFT-E-05-021 filtrate and previous sample's analysis

\begin{tabular}{|c|c|c|}
\hline $\begin{array}{c}\text { Sample ID } \\
\text { Analysis }\end{array}$ & HFT-E-05-021 & CBU-PIT-2005-00066 \\
\hline \multicolumn{3}{|c|}{ ICP-ES } \\
\hline $\mathrm{A} 1, \mathrm{mg} / \mathrm{L}$ & $2.31 \mathrm{E} 3$ & $2.18 \mathrm{E} 3$ \\
\hline $\mathrm{B}, \mathrm{mg} / \mathrm{L}$ & $4.60 \mathrm{E} 2$ & $4.43 \mathrm{E} 2$ \\
\hline $\mathrm{Na}, \mathrm{mg} / \mathrm{L}$ & $8.79 \mathrm{E} 4^{\star}$ & $6.93 \mathrm{E} 4$ \\
\hline $\mathrm{S}, \mathrm{mg} / \mathrm{L}$ & $3.2 \mathrm{E} 2$ & $\mathrm{NM}$ \\
\hline $\mathrm{K}, \mathrm{mg} / \mathrm{L}$ & $2.67 \mathrm{E} 2$ & $2.48 \mathrm{E} 2$ \\
\hline \multicolumn{3}{|c|}{ AA } \\
\hline K, mg/L & $2.54 \mathrm{E} 2$ & - \\
\hline $\begin{array}{l}\mathrm{NM}=\text { Not Measured } \\
\text { * Increase due to addition of NaOH. }\end{array}$
\end{tabular}

\subsection{IN-CELL SLURRY SAMPLE RESULTS}

Personnel performed analyses in the shielded cell, because of the high radioactivity of the samples. Solids analyses, slurry titration and density analyses were analyzed in duplicate.

\subsubsection{Dissolved Solids and Density Analysis}

Based on triplicate analysis, the slurry total solids is $20.19 \pm 0.08 \%$ and the filtrate dissolved solids content is $17.68 \pm 0.14 \%$. Table 17 shows the gravimetric results from duplicate samples analysis. We calculate the value for the insoluble solids $(3.05 \pm 0.15 \mathrm{wt} \%)$ using the following formula. ${ }^{9}$

$$
\begin{aligned}
& \text { Insoluble Solids }=\frac{(\text { total solids }- \text { dissolved solids })}{(1-\text { dissolved solids } / 100)} \\
& \text { Insoluble Solids }=(20.19-17.68) /(1-17.68 / 100)=3.05 \pm 0.15 \mathrm{wt} \% \\
& \text { Soluble Solids }=20.19-3.05=17.14 \pm 0.15 \mathrm{wt} \%
\end{aligned}
$$

Based on this calculation, the insoluble solids measurement is consistent with previous analyses $(1.69 \pm 0.22 \%$ for Ref.3, $2.18 \pm 0.61$ for Ref. 10 , and $2.3 \%$ for Ref. 9$) .{ }^{9,10}$ The insoluble solids measurement has a range of $2.9 \mathrm{wt} \%$ to $3.2 \mathrm{wt} \%$ based on the calculated uncertainties. This overlaps with the sum of the measured KTPB, MST, iron, aluminum, silicon and insoluble organics as shown in Table 18. 
WSRC-TR-2005-00358, REV 0

Table 17. The gravimetric properties of HTF-E-05-021 filtrate sample.

\begin{tabular}{|c|c|c|c|c|}
\hline & Sample 1 & Sample 2 & Average & $\begin{array}{c}\text { Sample } \\
\text { HTF-E-04-049 } \\
\text { and HTF-E-0050 } \\
\text { (Molar) }\end{array}$ \\
\hline $\begin{array}{c}\text { Total Dissolved } \\
\text { Solids (wt\%) }\end{array}$ & 17.42 & 17.94 & $17.68 \pm 0.26$ & 17.68 \\
\hline Density $(\mathrm{g} / \mathrm{mL})$ & 1.14 & 1.14 & $1.14 \pm 0.06$ & 1.164 \\
\hline
\end{tabular}

Table 18. Composition of the total solid mass for 1 gram of dried solids.

\begin{tabular}{|c|c|c|}
\hline Component & $\mathrm{g} / \mathrm{g}$ dry solid & $\begin{array}{c}\text { Analytical } \\
\text { Method }\end{array}$ \\
\hline Amount of MST $\left(\mathrm{NaTi}_{2} \mathrm{O}_{5} \mathrm{H}\right)$ & 0.0073 & ICP-ES (Table 5) \\
\hline Amount of Hematite $\left(\mathrm{Fe}_{2} \mathrm{O}_{3}\right)$ & 0.001 & ICP-ES (Table 5) \\
\hline Amount of Gibbsite $\left(\mathrm{Al}(\mathrm{OH})_{3}\right)$ & 0.025 & ICP-ES (Table 5) \\
\hline Chromium $\left(\mathrm{Cr}_{2} \mathrm{O}_{3}\right)$ & 0.001 & ICP-ES (Table 5) \\
\hline $\mathrm{KTPB}$ & 0.101 & AA \\
\hline Organics & 0.0041 & SVOA \\
\hline Silicon $\left(\mathrm{SiO}_{2}\right)$ & 0.0013 & ICP-ES \\
\hline Sum of all of the above (IS) & 0.1384 & - \\
\hline Measured Dissolved solids & 0.8494 & Weight \\
\hline Sum Dissolved Solid + Insoluble Solids & $0.988 \mathrm{~g}$ & - \\
\hline Expected Dried Total Solids & $1 \mathrm{~g}$ & - \\
\hline g/gdry= g/L x (1/slurry density) $\times(100 /$ Total solids) x (mol. Wt compound/mol. Wt element) \\
\hline
\end{tabular}

\subsubsection{In-cell Slurry Density}

Technicians determined density from the average of triplicate measurements of the Tank $48 \mathrm{H}$ slurry. Based on these measurements, the density of the Tank $48 \mathrm{H}$ slurry equals $1.165 \pm$ $0.002 \mathrm{~g} / \mathrm{mL}\left(\right.$ at $\left.24^{\circ} \mathrm{C}\right)$.

\subsection{ANALYSIS OF DATA}

Completion of an anion and cation balance provides a consistency check on the data. By comparing filtrate potassium and cesium concentrations, information on the decomposition rate for tetraphenylborate in Tank $48 \mathrm{H}$ can be obtained.

\subsection{TANK 48H ION BALANCE}

The sum of the major cations exceeds the sum of the major anions by $\sim 19 \%$. We attribute this significant difference to low carbonate values obtained from titration tests of the filtrate. Personnel reported observing precipitates during the process. We believe the carbonate level should range around 0.4 Molar. Table 19 sums the anions and cations using the filtrate analyses for the major components. 
Table 19. Tank 48H Filtrate Anion/Cation Balance

\begin{tabular}{|c|c|c|c|}
\hline Analyte & Moles ions & $\begin{array}{c}1 \sigma \text { Uncertainty } \\
\text { moles }\end{array}$ & Method \\
\hline $\mathrm{Al}(\mathrm{OH})_{4}{ }^{-}$ & 0.085 & 0.000 & ICP-ES \\
\hline $\mathrm{BO}_{3}^{3-}$ & 0.043 & 0.001 & ICP-ES \\
\hline $\mathrm{C}_{2} \mathrm{O}_{4}{ }^{2-}$ & 0.016 & 0.001 & IC \\
\hline $\mathrm{Cl}^{-}$ & 0.014 & 0.003 & IC \\
\hline $\mathrm{COOH}^{-}$ & 0.004 & 0.005 & IC \\
\hline $\mathrm{CO}_{3}{ }^{2-}$ & $0.385^{*}$ & 0.001 & Titration \\
\hline $\mathrm{NO}_{2}^{-}$ & 0.516 & 0.032 & IC \\
\hline $\mathrm{NO}_{3}^{-}$ & 0.230 & 0.012 & IC \\
\hline $\mathrm{OH}^{-}$ & 1.34 & 0.007 & Titration \\
\hline $\mathrm{PO}_{4}{ }^{3-}$ & 0.005 & 0.001 & IC \\
\hline $\mathrm{SO}_{4}{ }^{2-}$ & 0.003 & 0.001 & IC \\
\hline Total Anions & 3.14 & 0.06 & Calculation \\
\hline $\mathrm{B}+$ & 0.042 & 0.001 & ICP-ES \\
\hline $\mathrm{K}+$ & 0.006 & 0.005 & $\mathrm{AA}$ \\
\hline $\mathrm{Na}+$ & $3.82^{\#}$ & 0.029 & ICP-ES \\
\hline Total Cations & 3.87 & 0.03 & Calculation \\
\hline
\end{tabular}




\subsection{SUMMARY}

Personnel analyzed samples taken from Tank 48H on August 23, 2004 for chemical and radiological constituents. This report documents the analytical results and analysis of this data.

The results demonstrate that samples pulled in September 2003 and August 2004 are very similar in chemical composition. The free hydroxide concentration, sodium concentration, soluble solids and density have all increased as expected due to the addition of 6,424 gallons and 3,019 gallons of $50 \mathrm{wt} \%$ sodium hydroxide, repectively, in October 30, 2003 and December 7, 2004.

Data collected during sampling is summarized in Appendix B. 


\subsection{ACKNOWLEDGEMENTS}

This task required the support of a large team of people. We thank the following individuals but note that many others assisted in completing this task.

We thank the dedicated Shielded Cells Technicians, especially Monica Jenkins for receiving the Tank $48 \mathrm{H}$ sample, completing the analyses in the cells as requested and preparing the hundreds of samples for transfer to ADS.

We thank the following personnel in the Analytical Development Section for analyzing samples in a busy time period. We list the researchers involved but omit the many technicians supporting them to complete this task on schedule. Thanks to Leigh Brown, John Young, Tom White, Robert Ray, Curtis Johnson, David DiPrete, Ceci DiPrete, June Hart, Bill Boyce, Chuck Coleman, and Damon Click.

We appreciate the continued support of our WPT technician, Sharon Smith, who prepared the sample bottles for the shielded cells technicians and verified that the written instructions accomplished the intended tasks.

We appreciate the support of the Tank $48 \mathrm{H}$ team, for their technical support in helping us accomplish this task. 
Appendix A - A picture of the Slurry Sampler

T48 4L Sampler
(March, 05 Sampling)

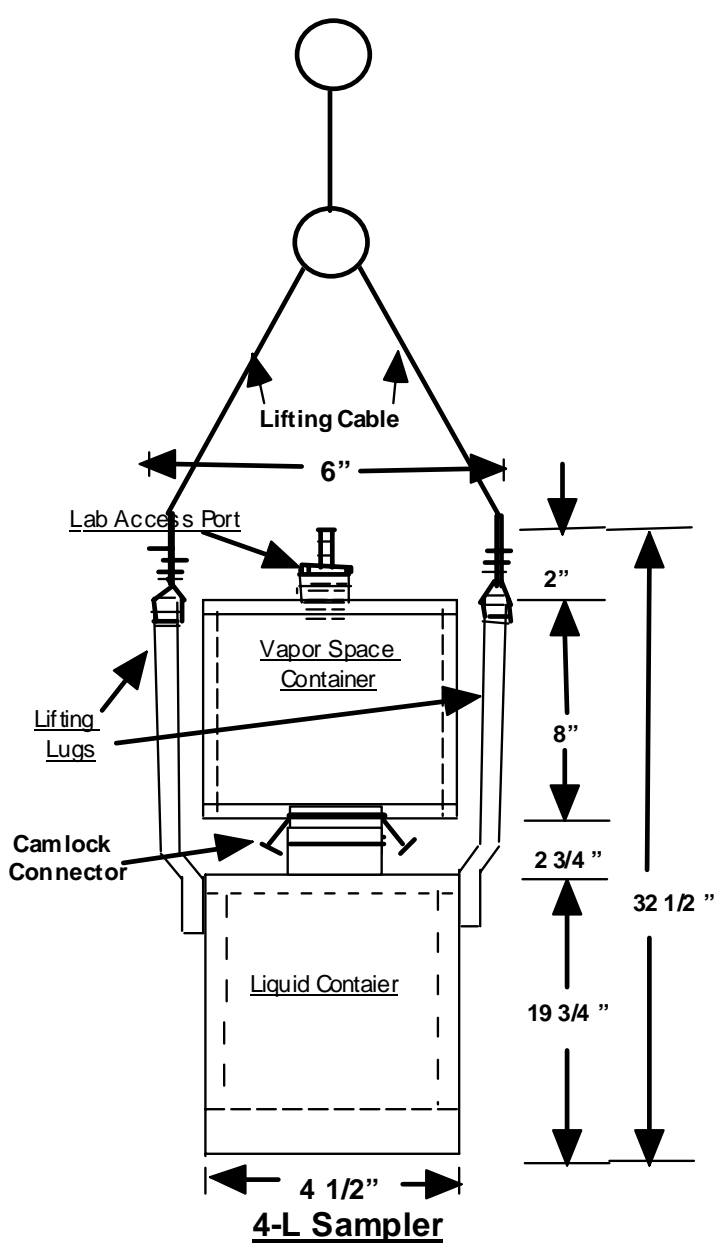

4 Liter Sampler Conceptual Sketch

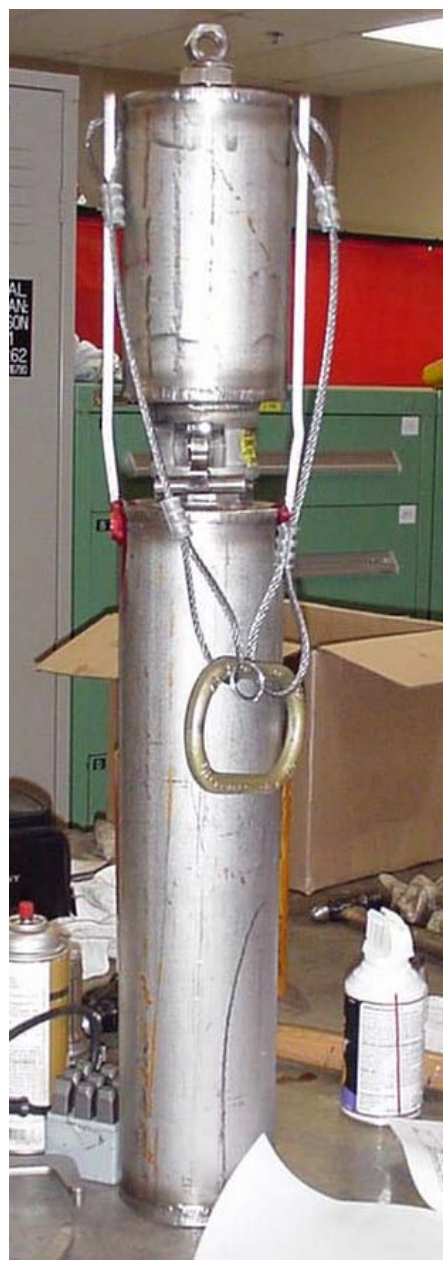

Photo of final fabricated sampler 
WSRC-TR-2005-00358, REV 0

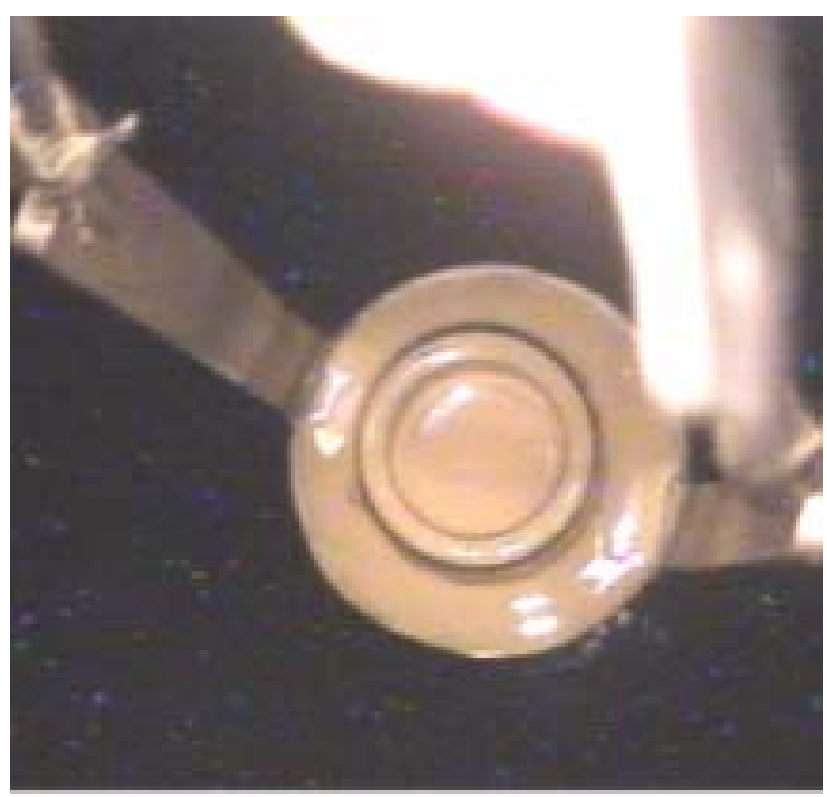

Full Sampler with T48 Material 
WSRC-TR-2005-00358, REV 0

Appendix B - Tank 48H Sample Results Summary

\begin{tabular}{|c|c|c|c|}
\hline Analyte & Slurry & Filtrate & Source \\
\hline Volume, gal & 242,190 & NM & Tank $48 \mathrm{H}$ \\
\hline Density, mg/L & 1.165 & 1.14 & Density \\
\hline Total Solids, wt \% & $20.19 \%$ & $17.68 \%$ & Solids \\
\hline Total Insolubles & $3.05 \%$ & NM & Calculation \\
\hline KTPB, wt \% & $2.01 \%$ & $<0.001 \%$ & HPLC \\
\hline MST solids, wt $\%$ & $0.15 \%$ & $(<0.15 \mathrm{mg} / \mathrm{L})$ & ICP-ES \\
\hline \multicolumn{4}{|l|}{$\underline{\text { Anions }}$} \\
\hline Free Hydroxide, $\mathrm{M}$ & NM & 1.34 & Titration \\
\hline Carbonate, $\mathrm{M}$ & NM & $0.385^{*}$ & Titration \\
\hline Nitrite, $\mathrm{mg} / \mathrm{L}$ & NM & 23750 & $\mathrm{IC}$ \\
\hline Nitrate, $\mathrm{mg} / \mathrm{L}$ & NM & 14250 & $\mathrm{IC}$ \\
\hline Oxalate, $\mathrm{mg} / \mathrm{L}$ & NM & 1440 & $\mathrm{IC}$ \\
\hline Formate, $\mathrm{mg} / \mathrm{L}$ & $\mathrm{NM}$ & 502 & $\mathrm{IC}$ \\
\hline Chloride, $\mathrm{mg} / \mathrm{L}$ & NM & 172 & $\mathrm{IC}$ \\
\hline Fluoride, mg/L & NM & 14 & $\mathrm{IC}$ \\
\hline Phosphate, $\mathrm{mg} / \mathrm{L}$ & NM & 428 & $\mathrm{IC}$ \\
\hline Sulfate, $\mathrm{mg} / \mathrm{L}$ & $\mathrm{NM}$ & 323 & $\mathrm{IC}$ \\
\hline \multicolumn{4}{|l|}{ Organic Species } \\
\hline TPB Anion, mg/L & 21,000 & $<10$ & HPLC \\
\hline $3 \mathrm{~PB}, \mathrm{mg} / \mathrm{L}$ & 74 & $<10$ & HPLC \\
\hline $2 \mathrm{~PB}, \mathrm{mg} / \mathrm{L}$ & 142 & $<10$ & HPLC \\
\hline $1 \mathrm{~PB}, \mathrm{mg} / \mathrm{L}$ & 151 & $<10$ & HPLC \\
\hline Phenol, mg/L & 771 & 535 & HPLC \\
\hline Nitrobenzene, mg/L & 180.6 & $<10$ & SVOA/HPLC \\
\hline $\begin{array}{l}\text { Nitrososbezene, } \\
\mathrm{mg} / \mathrm{L}\end{array}$ & 25.3 & $<10$ & SVOA/HPLC \\
\hline 4phenylphenol, mg/L & $<50$ & $<10$ & HPLC \\
\hline 2phenylphenol, mg/L & $<50$ & $<10$ & HPLC \\
\hline $\begin{array}{l}\text { Diphenylamine, } \\
\mathrm{mg} / \mathrm{L}\end{array}$ & $<50$ & $<10$ & HPLC \\
\hline Biphenyl, mg/L & 420 & $<10$ & HPLC \\
\hline o-terphenyl, mg/L & $<50$ & $<10$ & HPLC \\
\hline m-terphenyl, mg/L & $<50$ & $<10$ & HPLC \\
\hline p-terphenyl, mg/L & 182.0 & $<10$ & SVOA/HPLC \\
\hline benzene, $\mathrm{mg} / \mathrm{L}$ & 17.9 & $<10$ & SVOA/HPLC \\
\hline
\end{tabular}


WSRC-TR-2005-00358, REV 0

\begin{tabular}{|c|c|c|c|}
\hline Metals & Slurry & Filtrate & Source \\
\hline Potassium, mg/L & 2310 & 267 & AA \\
\hline $\mathrm{Hg}, \mathrm{mg} / \mathrm{L}$ & $<10.23^{*}$ & NM & AA \\
\hline Sodium, mg/L & 74980 & 87899 & ICP-ES \\
\hline Aluminum, mg/L & 2014 & 2210 & ICP-ES \\
\hline Boron, mg/L & 867 & 460 & ICP-ES \\
\hline${ }^{133}$ Cesium, mg/L & 12 & NM & ICP-MS \\
\hline Sulfur, mg/L & 378 & 320 & ICP-ES \\
\hline Phosphorus, mg/L & 129 & NM & ICP-ES \\
\hline Silicon, mg/L & 125 & $<125$ & ICP-ES \\
\hline Iron, $\mathrm{mg} / \mathrm{L}$ & 169 & $<3$ & ICP-ES \\
\hline Chromium, mg/L & 70 & $\mathrm{NM}$ & ICP-ES \\
\hline Magnesium, mg/L & 19 & $<1$ & ICP-ES \\
\hline Calcium, mg/L & 43 & NM & ICP-ES \\
\hline Molybdenum, mg/L & $<0.05$ & NM & ICP-ES \\
\hline Antimony, mg/L & $<0.46$ & NM & ICP-ES \\
\hline Zinc, $\mathrm{mg} / \mathrm{L}$ & 5 & NM & ICP-ES \\
\hline Manganese, mg/L & 6 & $<1$ & ICP-ES \\
\hline Strontium, mg/L & 9 & $\mathrm{NM}$ & ICP-ES \\
\hline Barium, mg/L & $<0.09$ & $<6$ & ICP-ES \\
\hline Copper, mg/L & 4 & $<3$ & ICP-ES \\
\hline Total Ag, mg/L & $<0.73$ & $\mathrm{NM}$ & ICP-MS \\
\hline Total Pd, mg/L & Prep. Interference & $\mathrm{NM}$ & ICP-MS \\
\hline Total Rh, mg/L & $<0.7$ & NM & ICP-MS \\
\hline Total Ru, mg/L & $<1.16$ & NM & ICP-MS \\
\hline Total Cd, mg/L & 0.014 & NM & ICP-MS \\
\hline Total $\mathrm{Hg}, \mathrm{mg} / \mathrm{L}$ & $<0.45^{*}$ & NM & ICP-MS \\
\hline Tc-99, mg/L & 1.23 & NM & ICP-MS \\
\hline Th-232, mg/L & NM & $1.95 \mathrm{E}-02$ & ICP-MS \\
\hline $\mathrm{Np}-237, \mathrm{mg} / \mathrm{L}$ & 0.173 & 0.0186 & ICP-MS \\
\hline $\mathrm{Pu}-239, \mathrm{mg} / \mathrm{L}$ & $<0.045$ & $<0.05$ & ICP-MS \\
\hline $\mathrm{U}-233, \mathrm{mg} / \mathrm{L}$ & $<0.09$ & 0.01 & ICP-MS \\
\hline $\mathrm{U}-234, \mathrm{mg} / \mathrm{L}$ & 0.267 & 0.0713 & ICP-MS \\
\hline $\mathrm{U}-235, \mathrm{mg} / \mathrm{L}$ & 0.564 & 0.1431 & ICP-MS \\
\hline $\mathrm{U}-236, \mathrm{mg} / \mathrm{L}$ & 0.125 & 0.031 & ICP-MS \\
\hline $\mathrm{U}-238, \mathrm{mg} / \mathrm{L}$ & 3.32 & 0.825 & ICP-MS \\
\hline U Total, mg/L & 4.48 & 1.1 & ICP-MS \\
\hline Cs-137, dpm/mL & $7.53 \mathrm{E}+08$ & $3.0 \mathrm{E}+07$ & ICP-MS \\
\hline
\end{tabular}




\subsection{References}

1 W. B. Dean, "Aggregation Temperature Impact of Caustic Additions for Tank 48H Disposition,” CBU-PIT-2005-00036, February 15, 2005.

2 T. B. Peters, D. P. Lambert, M. E. Stallings, and S. D. Fink, "Task Technical and Quality Assurance Plan for Destruction of Tetraphenylborate in Tank 48H", WSRCRP-2003-00396, Rev. 1, June 10, 2003.

3 D. P. Lambert, T. B. Peters, M. J. Barnes, and S. D. Fink, "Analysis of Tank 48H sample HTF-E-04-049 and HTF-E-04-050 (August 23, 2004)," WSRC-TR-200400514, Revision 0, November 2004.

4 W. B. Dean, "Task Technical Request for Analysis of March 2005 Tank 48H Sample," SP-TTR-2005-00020, May 3, 2005.

5 D. P. Lambert and S. D. Fink, "Task Technical and Quality Assurance Plan Analysis of March 2005 Tank 48H Sample,” WSRC-RP-2005-01569, Rev. 0, May 2005.

6 D. T. Hobbs, M. J. Barnes, R. A. Peterson, and C. L. Crawford, "Radioactive Testing Results in Support of the In-Tank Precipitation Facility", WSRC-TR-98-00070, Rev. 0, April 2, 1998.

7 E. T. Ketusky, CBU-PIT-2005-00066 (Tank 48 Best Estimate Chemical Characterization as of March 17, 2005

8 E. T. Ketusky, CBU-PIT-2005-00046 (Tank 48 Radionuclide Characterization to Support Material Disposition)

9 D. D. Walker, W. T. Boyce, C. J. Coleman, D. P. DiPrete, T. B. Edwards, A. A. Ekechuckwu, C. W. Hsu, S. F. Peterson, L. L. Tovo, and M. J. Whitaker, "Tank 48H Waste Composition and Results of Investigations of Analytical Methods", WSRCTR-97-0063, April 2, 1997.

10 D. P. Lambert, T. B. Peters, M. E. Stallings, and S. D. Fink, "Analysis of Tank 48H Samples HTF-E-03073 (June 03, 2003) and HTF-E-03-127 (September 17, 2003)" WSRC-TR-2003-00720, January 20, 2004. 